\title{
Comparison of Usefulness of Ultrasound-Guided Fine Needle Aspiration and Core Needle Biopsy in Diagnosis of Cervical Lymphadenopathy
}

\author{
Ju Yong Kang, Jung Jun Kim, Brian Kim, Myung-Chul Lee, and Ik Joon Choi \\ Department of Otorhinolaryngology-Head and Neck Surgery, Korea Cancer Center Hospital, \\ Korea Institute of Radiological and Medical Science, Seoul, Korea
}

\author{
경부 림프절 진단에서 초음파 유도하 세침흡인검사와 중심바늘생검의 유용성 비교 \\ 강주용 · 김정준 · 김브라이언 · 이명철 · 최익준 \\ 한국원자력의학원 원자력병원 이비인후-두경부외과
}

\author{
Received December 28, 2020 \\ Revised March 16, 2021 \\ Accepted March 18, 2021 \\ Address for correspondence \\ Ik Joon Choi, MD, PhD \\ Department of Otorhinolaryngology- \\ Head and Neck Surgery, \\ Korea Cancer Center Hospital, \\ Korea Institute of Radiological \\ and Medical Science, \\ 75 Nowon-ro, Nowon-gu, \\ Seoul 01812, Korea \\ Tel $+82-2-970-1271$ \\ Fax +82-2-970-2450
}

E-mail ijchoiorl@gmail.com
Background and Objectives The purpose of this study is to compare diagnostic outcome and safety of fine needle aspiration (FNA) and core needle biopsy (CNB) in patients with cervical lymphadenopathy.

Subjects and Method This retrospective studies were conducted on 164 cases with cervical lymphadenopathy that had undergone FNA, and 44 cases that had undergone CNB. The cytopathological results from FNA and CNB were compared with the histopathological results confirmed by excisional biopsy in the nodes according to different sizes and radiological levels, respectively. Diagnostic sensitivity, specificity, positive predictive value (PPV), negative predictive value (NPV), and accuracy were evaluated according to disease entities.

Results FNA is more accurate than CNB in most of the sizes and at all cervical levels. However, there is no statistically significant difference between the results of the two tests. Sensitivity and NPV for diagnosis of malignant lymphoma are higher with FNA than with CNB. However, specificity and PPV for malignant lymphoma are higher with CNB than with FNA. Also CNB showed superior sensitivity, PPV and NPV for metastatic lymphadenopathy.

Conclusion Although CNB is beneficial in reducing the false negative rate, it still has several limitations. Since CNB has no statistically significant advantage over FNA, FNA can be a good alternative method with less complication and high diagnostic value for lesions where CNB is difficult to perform. Korean J Otorhinolaryngol-Head Neck Surg 2021;64(8):568-75

Key Words Aspiration, fine needle $\cdot$ Core needle biopsy · Lymphoma ·

Metastasis, carcinoma $\cdot$ Neck, lymphadenopathy.
서 론

두경부 영역은 림프절이 잘 발달되어 있어서, 양성림프절 종물부터 악성 림프절 종물까지 다양하게 관찰될 수 있다. 림 프절 종물의 양성 및 악성 여부를 감별하고 올바른 치료 계

This is an Open Access article distributed under the terms of the Creative Commons Attribution Non-Commercial License (https://creativecommons.org/licenses/by-nc/4.0) which permits unrestricted non-commercial use, distribution, and reproduction in any medium, provided the original work is properly cited.
획을 세우기 위해서는 정확한 병리학적 진단이 필요하다. 이 에 세침흡인검사를 일차검사법으로 널리 이용하고 있다. 세 침흡인검사는 안전하며, 시행하기 쉽고, 환자에게 고통을 덜 주며 암세포들에 의한 오염의 위험성이 낮아서 림프절 종물 을 포함한 모든 두경부 종괴 감별에 선별검사로 사용된다. ${ }^{1-3)}$ 하지만 세침흡입검사에는 부적절한 검체 결과로 인해 최대 $14.6 \%$ 의 위음성률을 보이며, 추가적으로 반복 세침흡인검사 를 필요로 하거나, 수술적 절개 생검이 필요한 경우가 있다. ${ }^{4}$ 
이를 극복하기 위해 최근에 중심바늘생검을 다양한 두경부 종괴 진단검사법에 도입하였고, 세침흡입검사와 병행하거나 세침흡입검사로 진단이 내려지지 않은 종괴의 경우 단독적으 로 이용되기도 한다. 최근 들어 몇몇 문헌에서 중심바늘생검 이 높은 정확도를 바탕으로 두경부 종괴 진단의 gold standard로 자리잡을 수 있음을 강조하는 보고가 있었다. ${ }^{5,6)}$ 이미 갑상선 및 타액선 종괴 진단 및 악성 림프종 아형 분류를 위 해 다양하게 사용되고 있다. 하지만 중심바늘생검은 크기가 작은 림프절 종물에서나 복잡한 해부학적 구조를 지닌 부위 에서 검사를 진행하는데 어려움이 있으며, 주위 조직 손상으 로 혈종, 일시적 감각저하, 종양 세포 파급 등의 합병증을 유 발할 가능성이 높아서 고려해야 할 사항들이 많다. ${ }^{7)}$ 이에 본 저자들은 두경부 영역 중 림프절 종물의 감별을 위해 두 방법의 진단적 유용성을 비교 분석하였고, 중심바늘생검과 비교하였을 때 초음파 유도하 세침흡인검사의 진단적 가치에 대해 알아보고자 한다.

\section{대상 및 방법}

\section{대 상}

2017년 8월에서 2020년 4월까지 한국원자력의학원 원자력 병원 이비인후-두경부외과에서 1 명의 이비인후-두경부외과 의가 경부 림프절 종물에서 시행한 초음파 유도하 세침흡인 검사 164예와, 2018년 1월에서 2020년 4월까지 시행한 중심 바늘생검 44예의 결과를 바탕으로 연구 대상을 정하였다.

\section{방 법}

이 중 39예에서 두 검사를 같이 진행하였으며, 의무기록을 바탕으로 후향적으로 검토하였다. 술자의 경험을 바탕으로 세침흡인검사가 숙달된 이후 2018년 1월부터 중심바늘생검 을 시행하였다. 세침흡인검사 중 30예에서, 중심바늘생검 중 23예에서 진단 및 치료목적으로 수술과 절개생검 및 중심바 늘생검을 통한 면역조직화학검사를 통해 최종 조직검사를 확인하였다. 연구의 선정 기준으로는 외부에서 촉진되어 경 부림프절 종물로 의심되는 종대 및 초음파 검사상 우연히 발 견된 림프절 종물을 포함시켰다.

진단학적 방법으로 ARIETTA65(Hitachi Medical Systems Europe Holding AG, Zug, Switzerland) 초음파의 3 15 $\mathrm{MHz}, 5.5 \mathrm{~cm}$ probe를 이용하여 림프절 종물을 검사하였고, 23 gauge, $6.0 \mathrm{~cm}$ 바늘을 이용하여 세침흡인검사를 시행하였 으며, 18 gauge, $10.0 \mathrm{~cm}$ 스프링 활성화 코어 바늘로 구성된 자동 중심바늘을 이용하여 중심바늘생검법을 실행하였다. 세 침흡인검사는 목표 결절에 도달하면 10 15회 이상의 왕복 운
동을 진행하여 흡인하였다. 중심바늘생검을 시행하는 경우에 는 유도 바늘을 이용하여 결절까지의 길을 만들어 놓고, 유 도바늘의 방향만 조절하여, 어시스트의 도움을 받아서 중심 바늘생검 바늘을 3 5회 이상 통과하면서 조직을 충분히 얻 었다. 모든 검사를 진행하기 앞서 환자 및 보호자에게 검사 방법 및 발생할 수 있는 합병증에 대하여 설명하여 동의를 받고, 절차에 따라 진행하였다.

세침흡인검사에 의한 세포학적 진단은 부적절한 검체, 양성 림프결절, 비정형세포, 악성 림프결절로 분류하였다. 세포를 발견하지 못했거나, 혈액만 흡인된 경우를 부적절한 검체로 정하였고, 양성 림프결절에는 반응성 림프절 비대, 만성 육아 종성 염증, 염증 세포, 새열낭종, 기쿠치씨병 등을 포함시켰다. 악성 림프결절에는 악성 림프종과 전이성 림프절 종물로 분류 하였고, 그 외 비정형세포로 세포학적 검사 결과를 나누었다. 중심바늘생검의 조직학적 진단도 동일한 기준으로 분류하였 다. 최종 조직학적 검사까지 확인한 증례 결과를 바탕으로 세 침흡인검사와 중심바늘생검의 정확도를 확인하였다. 또한 두 검사를 동시에 시행한 증례 결과를 바탕으로 두 검사를 같이 시행하였을 때 정확도를 확인하였다.

\section{통 계}

통계적 분석은 Window용 SPSS 프로그램(version 23.0, IBM Corp., Armonk, NY, USA)을 사용하여 chi-square test 및 Mann-Whitney test, 선형 대 선형결합을 이용하여 비교 분석하였다. $p<0.05$ 를 통계학적으로 의미가 있다고 하였다. 추가로 악성림프결절(악성 림프종, 전이성 림프절 종물)에서 두 검사의 민감도, 특이도, 양성 예측값(positive predictive value, PPV) 및 음성 예측값(negative predictive value, $\mathrm{NPV}$ 를 통해 각 검사의 정확성 및 효용성을 평가하였다. 본 연구는 본원의 기관생명윤리위원회 심의를 통과하였다(IRB No. 2020-12-002).

\section{결 과}

본 연구에서 분석한 164 예의 세침흡인검사와 44 예의 중심 바늘생검의 림프절 종물은 좌측, 우측의 비율이 각각 53.0: 47.0, 34.1:65.9( $p=0.013)$ 였고, 평균 사이즈가 각각 $18.3 \pm 0.9$ $\mathrm{mm}, 25.8 \pm 2.0 \mathrm{~mm}(p<0.001)$ 였고, 림프절 종물의 위치는 다 소 차이가 있으나 level II에 위치한 림프결절이 각각 $36.0 \%$, $43.2 \%$ 로 가장 많았다 $(p=0.442)$. 세침흡인검사 중 $5.5 \%$ 에서 비진단적 검체 비율을 확인하였고, 중심바늘생검 검사에서 는 비진단적 결과는 없었다 $(p=0.073)$ (Table 1). 두 검사 결과 의 질환별 빈도를 확인해보면 세침흡입검사의 $61.6 \%$ 가 양성 
Table 1. Clinical information and analysis of clinical outcome for the FNAC and CNB groups in cervical lymphadenopathy group

\begin{tabular}{|c|c|c|c|}
\hline & FNAC $(n=164)$ & CNB $(n=44)$ & $p$ value \\
\hline Age (year) & $48.7 \pm 1.5$ & $57.8 \pm 3.1$ & $0.008^{*}$ \\
\hline Sex & & & $0.011^{\dagger}$ \\
\hline Male & $83(50.6)$ & $33(75.0)$ & \\
\hline Female & $81(49.4)$ & $11(25.0)$ & \\
\hline \multicolumn{4}{|l|}{ Region } \\
\hline Right & $87(53.0)$ & $15(34.1)$ & 0.010 \\
\hline Left & $77(47.0)$ & $29(65.9)$ & \\
\hline Size $(\mathrm{mm})$ & $18.3 \pm 0.9$ & $25.8 \pm 2.0$ & $<0.001^{*}$ \\
\hline Neck level & & & $0.442^{\dagger}$ \\
\hline I & $15(9.1)$ & $2(4.5)$ & \\
\hline$\|$ & $59(36.0)$ & $19(43.2)$ & \\
\hline III & $29(17.7)$ & $11(25.0)$ & \\
\hline IV & $18(11.0)$ & $6(13.6)$ & \\
\hline$\vee$ & $40(24.4)$ & $6(13.6)$ & \\
\hline VI & $3(1.8)$ & $0(0.0)$ & \\
\hline Diagnosis & & & $0.073^{\dagger}$ \\
\hline Inadequate specimen & $9(5.5)$ & $0(0.0)$ & \\
\hline \multicolumn{4}{|l|}{ Benign } \\
\hline Reactive hyperplasia & $62(37.8)$ & $5(11.4)$ & \\
\hline Inflammatory cell & $2(1.2)$ & $0(0.0)$ & \\
\hline Chronic granulomatous lymphadenopathy & $18(11.0)$ & $4(9.1)$ & \\
\hline Brachial cleft cyst & $1(0.6)$ & $1(2.3)$ & \\
\hline Kikuchi's disease & $13(7.9)$ & $3(6.8)$ & \\
\hline Others & $5(3.0)$ & $3(6.8)$ & \\
\hline Atypical cell & $7(4.3)$ & $2(4.5)$ & \\
\hline \multicolumn{4}{|l|}{ Malignancy } \\
\hline Malignant neoplasm & $1(0.6)$ & $1(2.3)$ & \\
\hline Metastatic carcinoma & $13(7.9)$ & $4(9.1)$ & \\
\hline Malignant lymphoma & $12(7.3)$ & $10(22.7)$ & \\
\hline Metastatic SCC & $15(9.1)$ & $8(18.2)$ & \\
\hline Metastatic papillary carcinoma & $3(1.8)$ & $0(0.0)$ & \\
\hline Others & $3(1.8)$ & $3(6.8)$ & \\
\hline
\end{tabular}

Data are presented as $\mathrm{n}(\%)$. *Mann-Whitney test, ${ }^{\dagger}$ chi-square test. FNAC: fine needle aspiration cytology, CNB: core-needle biopsy, Benign others: negative for malignancy, SCC: squamous cell carcinoma, Malignancy others: metastatic adenocarcinoma, metastatic small cell carcinoma

으로 진단되었고, 세부적으로는 반응성 림프절 비대, 만성 육 아종성 림프절염, 기쿠치씨병, 기타, 염증 세포, 새열낭종 순 으로 빈도를 구성하였다. 중심바늘생검의 $36.3 \%$ 가 양성으로 진단되었고, 세부적으로는 반응성 림프절 비대, 만성 육아종 성 림프절염, 기쿠치씨병, 기타, 새열낭종 순으로 차지하였다. 각 검사 결과에서 비정형세포는 $4.3 \%, 4.5 \%$ 를 차지하였다. 그 외 세침흡인검사의 $28.7 \%$ 가 악성으로 진단되었는데 세부적 으로 전이성 암종, 전이성 편평상피세포암종, 악성 림프종, 유 두성 암종, 기타 암종, 악성종양 순으로 차지하였다. 중심바늘 생검 결과의 $59.1 \%$ 가 악성으로 진단되었고, 악성 림프종, 전 이성 편평상피세포암종, 전이성 암종, 기타 암종, 악성종양 순 으로 구성되었다(Table 1).
각각의 검사를 시행 후 수술 및 절개생검을 통해 최종 조 직학적 검사까지 진행한 증례는 세침흡인검사는 30예, 중심 바늘생검은 23예였다. 중심바늘생검을 진행한 23예에는 수 술 및 절개생검을 통해 확인된 19예와, 절개생검 없이 중심 바늘생검을 통해서 악성 림프종으로 진단되고 면역조직화학 검사까지 진행하여, 4 예에서 아형분류를 통해 진단되어 최종 조직결과를 확인하였다.

진단된 결과를 바탕으로 분석한 세침흡인검사의 정확도는 $90.0 \%(27 / 30)$ 였으며, 중심바늘생검의 정확도는 $75.0 \%(18 / 23)$ $(p=0.241)$ 였다. 이렇게 두 그룹으로 나누어 크기에 따른 각 검 사의 정확도를 비교 분석하였다. $10 \mathrm{~mm}$ 미만의 종괴는 최종 조직 검사까지 진행한 것이 1 예였으며, 세침흡인검사 결과와 
동일하였다. 그 외 크기에서는 다음과 같은 정확도를 보였다. 10 19 mm 종괴(90.9\%, 71.4\%, $p=0.293), 20 ~ 29 \mathrm{~mm}$ 종괴 (90.0\%, 83.3\%, $p=0.793), 30 \mathrm{~mm}$ 이상의 종괴(84.5\%, $77.8 \%$, $p=0.611)$ 로 확인할 수 있었다. 또한 영상학적으로 경부 림프 절의 위치를 6 개 level로 분류한 후, 각 위치에 따른 각 그룹 의 정확도를 확인하였다. Level I(100.0\%, 100.0\%), level II (91.7\%, 75.0\%, $p=0.319)$, level III(100.0\%, 80.0\%, $p=0.317$ ). level IV(75.0\%, 75.0\%, $p>0.999)$, level V(80.0\%, 66.7\%, $p=$ 0.866)로 확인되었으며, level VI는 1예만 세침흡인검사를 통 해 진행하였으며, 최종 조직검사와 일치하였다(Table 2). 최종 조직 병리결과를 바탕으로 각 검사의 정확도를 질환별로 비 교하였는데, 반응성 림프절 비대 $(80.0 \%, 66.7 \%, p=0.693)$, 새 열낭종은 각 그룹에 1예씩 진단되었으며, 최종 조직검사와 일 치한 것을 확인하였다. 하지만 새열낭종에서는 해당 환자수가 적어 통계적 유의성을 확인할 수 없었다. 악성 림프종(83.3\%, $80.0 \%, p=0.844)$, 전이성 편평상피세포암종 $(100 \%, 100 \%)$ 으로 확인되었다(Table 3).

본 연구에서 세침흡인검사와 중심바늘생검을 같이 시행한 경우는 43 예이며, 이 중에서 최종 조직검사까지 진행한 경우 는 15 예이다. 두 검사를 같이 시행한 군을 조합군으로 명칭하 였다. 여기에는 수술 및 절개 생검을 통해 진행한 경우와 중 심바늘생검을 통해 악성 림프종의 아형분류를 통해 최종 진 단이 내려진 경우를 모두 포함하였다. 두 검사를 같이 시행한 조합군의 결과 중 하나의 경과라도 최종 조직결과와 일치하 는지를 비교 분석하여 정확도를 평가하였고, 조합군의 정확도 는 80.0\%(12/15)였다. 조합군은 기존의 두 검사와 동일하게 크기에 따른 정확도, 경부 level에 따른 정확도를 비교 분석하 였고, 질환별 결과에 따른 결과도 확인하였다. 검사 시행한 크기별 정확도는 10 19 mm는 75.0\%, 20 29 mm는 100.0\%, $30 \mathrm{~mm}$ 이상의 림프절 종물에서 $66.7 \%$ 로 확인되었다. 위치 에 따른 정확도 비교는 level I에서는 $100.0 \%$, level II는 $85.7 \%$, level III는 $66.7 \%$, level IV \& V는 66.7\%의 정확도를 확인하 였다. 두 검사를 같이 진행하였을 때, 질환별 정확도는 반응 성 림프절 비대에서 $66.7 \%$, 새열낭종은 $100.0 \%$, 악성 림프종 은 $66.7 \%$, 전이성 편평세포암종에서 $100.0 \%$ 로 확인하였다 (Table 4).

마지막으로 악성 림프결절을 악성 림프종과 전이성 림프절 종물군으로 나누고, 민감도, 특이도, 양성 예측값(PPV) 및 음 성 예측값(NPV)를 통해 각 검사의 진단적 가치를 평가하였 다. 악성 림프종에서 각 검사의 민감도는 $76.9 \%, 63.6 \%$ 였으며, 특이도는 $99.3 \%, 100.0 \%$ 이며, 양성예측값은 $90.9 \%, 100.0 \%$ 이고, 음성예측값은 $98.0 \%, 88.9 \%$ 였다. 전이성 림프절 종물 군에서 민감도는 각각 $97.1 \%, 100.0 \%$ 이고, 특이도는 모두
Table 2. Diagnostic accuracy of the FNAC, CNB in different sizes and radiological neck lymph node levels

\begin{tabular}{|c|c|c|c|}
\hline & \multicolumn{2}{|c|}{ Diagnostic rate (\%) } & \multirow{2}{*}{$p$ value } \\
\hline & FNAC $(n=30)$ & CNB $(n=23)$ & \\
\hline Total & $27 / 30(90.0)$ & $18 / 23(75.0)$ & 0.241 \\
\hline \multicolumn{4}{|l|}{ Size $(\mathrm{mm})$} \\
\hline$x<10$ & $1 / 1(100.0)$ & $0 / 0(0.0)$ & \\
\hline $10 \leq x<20$ & 10/11 (90.9) & $5 / 7(71.4)$ & 0.293 \\
\hline $20 \leq x<30$ & $9 / 10(90.0)$ & 6/7 (83.3) & 0.793 \\
\hline$x \geq 30$ & $7 / 8(84.5)$ & $7 / 9(77.8)$ & 0.611 \\
\hline \multicolumn{4}{|l|}{ Neck level } \\
\hline । & $3 / 3(100.0)$ & $2 / 2(100.0)$ & \\
\hline$\|$ & $11 / 12$ (91.7) & $6 / 8(75.0)$ & 0.319 \\
\hline III & $5 / 5(100.0)$ & $4 / 5(80.0)$ & 0.317 \\
\hline IV & $3 / 4(75.0)$ & $3 / 4(75.0)$ & $>0.999$ \\
\hline$\vee$ & $4 / 5(80.0)$ & $3 / 4(66.7)$ & 0.866 \\
\hline $\mathrm{VI}$ & $1 / 1(100.0)$ & $0 / 0(0.0)$ & \\
\hline
\end{tabular}

FNAC: fine needle aspiration cytology, CNB: core-needle biopsy

Table 3. Comparison of accuracy between FNAC, CNB according to disease entities

\begin{tabular}{|c|c|c|c|}
\hline \multirow{2}{*}{ Definite diagnosis } & \multicolumn{2}{|c|}{ Diagnostic rate (\%) } & \multirow{2}{*}{$p$ value } \\
\hline & FNAC & CNB & \\
\hline \multicolumn{4}{|l|}{ Benign } \\
\hline Reactive hyperplasia & $4 / 5(80.0)$ & $2 / 3(66.7)$ & 0.693 \\
\hline $\begin{array}{l}\text { Chronic granulomatous } \\
\text { lymphadenopathy }\end{array}$ & & $0 / 1(0.0)$ & \\
\hline \multicolumn{4}{|l|}{ Kikuchi's disease } \\
\hline Brachial cleft cyst & $1 / 1(100.0)$ & $1 / 1(100.0)$ & \\
\hline Others & & 0/1 (0.0) & \\
\hline \multicolumn{4}{|l|}{ Malignancy } \\
\hline Malignant lymphoma & 10/12 (83.3) & $8 / 10(80.0)$ & 0.844 \\
\hline Metastatic carcinoma & $1 / 1(100.0)$ & & \\
\hline Metastatic SCC & 7/7 (100.0) & $6 / 6(100.0)$ & \\
\hline $\begin{array}{l}\text { Metastatic papillary } \\
\text { carcinoma }\end{array}$ & $3 / 3(100.0)$ & & \\
\hline Others & $1 / 1(100.0)$ & $1 / 1(100.0)$ & \\
\hline
\end{tabular}

FNAC: fine needle aspiration cytology, CNB: core-needle biopsy, SCC: squamous cell carcinoma

$96.2 \%$ 였으며, 양성예측값은 $86.8 \%, 94.4 \%$ 이고, 음성예측도 는 $99.2 \%, 100.0 \%$ 로 확인되었다(Table 5).

\section{고 찰}

임상적으로 두경부 림프절 종물 환자를 진료할 때, 양성과 악성 림프절을 정확하게 감별하고, 불필요한 침습적 시술 및 수술을 줄이는 노력을 하는 것이 중요하다. 대체적으로 세침 흡인검사를 선별 검사법으로 이용하고 있으며, 이를 통해 양 성림프절 종물과 악성 림프종이나 전이성 림프절 종물을 간 
Table 4. Accuracy of the combination group according to disease entities and different sizes and radiological neck lymph node levels

\begin{tabular}{|c|c|c|c|c|c|}
\hline \multirow[b]{2}{*}{ Total } & \multicolumn{5}{|c|}{ Diagnostic rate (\%) } \\
\hline & & & $12 / 15(80.0)$ & & \\
\hline \multirow[t]{2}{*}{ Size } & & $x<10$ & $10 \leq x<20$ & $20 \leq x<30$ & $x \geq 30$ \\
\hline & & & $3 / 4(75.0)$ & $5 / 5(100.0)$ & $4 / 6(66.7)$ \\
\hline \multirow[t]{2}{*}{ Neck level } & I & $\|$ & III & $I V \& V$ & \\
\hline & $2 / 2(100)$ & $6 / 7(85.7)$ & $2 / 3(66.7)$ & $2 / 3(66.7)$ & \\
\hline \multirow[t]{2}{*}{ Definite diagnosis } & & Reactive hyperplasia & $\mathrm{BCC}$ & Malignant lymphoma & Metastatic SCC \\
\hline & & $2 / 3(66.7)$ & $1 / 1(100.0)$ & $4 / 6(66.7)$ & $5 / 5(100.0)$ \\
\hline
\end{tabular}

Combination group: the group performed both fine needle aspiration cytology and core-needle biopsy, BCC: brachial cleft cyst, SCC: squamous cell carcinoma

Table 5. Diagnostic accuracy of the FNAC, CNB groups according to disease entities

\begin{tabular}{lcccccccc}
\hline & TP & TN & FP & FN & Sensitivity (\%) & Specificity (\%) & PPV (\%) & NPV (\%) \\
\hline $\begin{array}{l}\text { Malignant lymphoma } \\
\text { FNAC }\end{array}$ & 10 & 150 & 1 & 3 & 76.9 & 99.3 & 90.9 & 98.0 \\
CNB & 7 & 32 & 0 & 4 & 63.6 & 100.0 & 100.0 & 88.9 \\
$\begin{array}{l}\text { Metastatic lymphadenopathy } \\
\text { FNAC }\end{array}$ & & & & & & & & \\
CNB & 17 & 125 & 5 & 1 & 97.1 & 96.2 & 86.8 & 99.2 \\
\hline
\end{tabular}

FNAC: fine needle aspiration cytology, CNB: core-needle biopsy, TP: true positive, TN: true negative, FP: false positive, FN: false negative, PPV: positive predictive value, NPV: negative predictive value

단하게 감별할 수 있다. 세침흡인검사는 비용이 저렴하고, 국 소마취 없이 외래에서 비교적 간단하고 신속하게 진행할 수 있고, 주요 합병증의 위험없이 동시에 여러 부위를 검사할 수 있다. ${ }^{3,10-12)}$

반면 중심바늘생검은 조직을 얻는 술기이며, 세침흡인검사 에 비해 정확도가 높다고 하여 최근에 두경부 종괴의 진단 검 사로 주목 받고 있다. 이는 절개생검보다는 덜 침습적이지만, 국소 마취가 필요하고 통증, 출혈, 감염, 악성종양의 파종 위 험성이 남아있다. ${ }^{13)}$ 이를 극복하려면 숙련된 검사자가 초음 파 유도하에 정밀하게 검사를 시행하는 것이 유리하며, 시술 후 최소 20 30분 정도 검사 부위를 압박하여 출혈 가능성을 줄이는 것이 필요하다. ${ }^{14,15)}$ 세침흡인검사는 높은 특이도와 안 전성을 보여주지만 상대적으로 비진단 검체 비율이 높아서, 반복적인 검사 및 불필요한 수술이 필요하다는 제한점이 있 다. ${ }^{1)}$ 이는 진단에 필요한 세포가 흡인되지 않거나 그 양이 충 분하지 않은 경우 발생할 수 있다. 반면 중심바늘생검은 이 론적으로 충분하게 조직을 얻어서, 그 표본을 통해 면역조직 화학검사까지 진행할 수 있고, 이를 통해 비진단 검체 비율 을 낮출 수 있다는 장점이 있다. 본 연구의 세침흡인검사에서 $5.5 \%$ 의 비진단 검체 비율을 보인 반면, 중심바늘생검에서는 비진단적 결과는 확인되지 않았으며, 통계적으로 유의한 차이 는 확인되지 않았다. 세침흡인검사의 비진단 검체 비율을 줄 이기 위해서 영상학적으로 낭성 성분이 의심되는 부위를 피 하여 흡인을 하거나, 세침이 목표 결절에 도달하면 10 15회
이상의 왕복 운동하면서 흡인하여 충분한 검체를 얻게 되면 도움이 된다. 또한 보완적으로 중심바늘생검을 같이 이용할 경우 비진단 검체 비율을 줄일 수 있다고 한다. ${ }^{14)}$

하지만 중심바늘생검을 이용하는 데 여러 어려움이 있다. 첫째, $10 \mathrm{~mm}$ 미만의 종괴를 검사하는 것은 제한이 있다. 검 사장치에는 길이가 10 20 mm의 홈(notch)이 있는 유도 캐 뉼라(stylet cannula) 역할을 하는 내부 바늘이 있고, 장전 후 발사하면 외부 바늘 끝보다 내부 바늘이 전진하면서 조직을 얻게 된다. 크기가 작은 결절에서 내부 바늘 끝이 결절을 관 통하거나, 종괴 내에 원하는 부위에 내부 바늘의 홈을 정확하 게 위치하기 어려워서 원하는 조직을 얻기가 어렵다고 한다. ${ }^{16}$ 또한 작은 크기의 결절에서 중심바늘생검을 이용할 경우 주 변 조직이 손상 될 수 있는 가능성이 상대적으로 높아 어려 움이 있다. 반면 세침흡인검사는 $10 \mathrm{~mm}$ 이하의 작은 결절에 서도 주변 조직 손상 없이 정확하게 검체 채취가 가능하다.

둘째, 중심바늘생검은 큰 혈관과 신경 등의 주요 조직들이 협소한 공간에 복잡하게 이루어져 있는 상부 경부 림프절에 서 진행하기에 어려움이 있다. 이곳을 검사할 때는 충분한 해 부학적, 영상의학적 지식을 기반으로 주변 주요 조직 손상 없 이 정확하게 조준해야 하는데, 이는 혈종, 감각저하 등의 합 병증이 발생할 수 있는 위험성이 높기 때문이다. 본 연구에서 는 이러한 합병증을 보이는 증례는 없었으나, 섬세한 접근 및 조준을 위해서는 세침흡인검사가 중심바늘생검보다 유리하다 고 본다. 이러한 어려움을 극복하고, 숙련되기까지 학습곡선 
(learning curve)이 존재하며, 숙련도에 따라 진단적 결과가 유의하게 차이가 있다는 연구들도 보고된 바 있다. ${ }^{17)}$ 본 연구 에서도 경부 림프절을 진단할 때 5 개월간은 세침흡인검사만 을 시행하였고, 그 후로 술자가 경험 및 해부학적, 영상의학적 지식을 바탕으로 세침흡인검사법이 익숙해진 후에 중심바늘 생검을 시작하였다. 중심바늘생검을 시작한 초기에는 정확 한 검사 결과를 얻기 위해 보조적 장치로 동시에 세침흡인검 사를 병행하였다.

본 연구에서 대부분의 림프결절 크기에서 세침흡인검사가 중심바늘생검보다 높은 정확도를 보였고, 통계적으로 유의한 차이를 보이지 않았다. Level IV를 제외한 대부분의 경부 위 치에서 세침흡인검사가 중심바늘생검보다 높은 정확도를 보 였고, 통계적으로 유의한 차이를 보이지 않았다. 각 질환별 두 검사의 정확도를 비교 분석한 결과, 반응성 림프절 비대에서 는 세침흡인검사가 더 높은 정확도를 보였으며, 두경부 림프 종에서는 세침흡인검사의 정확도가 상대적으로 높게 확인되 었고, 전이성 림프절 종물군에서는 두 그룹의 정확도는 동일 하게 확인되었다. 이는 통계적으로 유의한 차이를 보이지 않 았다. 두 그룹의 정확도가 비슷하거나, 유의한 차이가 확인되 지 않는다면, 초음파 유도하 조직검사를 시행하는 초심자가 중심바늘생검의 진단적 제한점을 극복하면서까지 시행하기 보다는 세침흡인검사를 우선적으로 선택하는 것이 합당하다 고 생각한다.

악성 림프종의 정확한 진단을 위해서는 아형 분류가 필요 하며, 여기에는 면역조직 화학검사가 진행되어야 하며, 이 과 정을 통해야만 정확한 분류 및 치료 계획을 세울 수 있다. 전 통적으로 세침흡인검사를 통해 진단할 때 림프종이 의심되 면 절개 생검을 통하여 충분한 조직을 얻은 후, 면역조직화학 적으로 아형 분류를 추가로 진행하였다. 하지만 절개 생검은 창상치유의 지연 및 흥터의 문제, 혈관 및 신경 등의 주요 조 직 손상의 위험성이 높은 문제점이 있다. 이를 보완하기 위해 최근 들어 조직을 채취한 후 면역조직 화학검사까지 진행할 수 있는 중심바늘생검법을 이용하여, ${ }^{13,18,19)}$ 절개생검법의 진 단 과정의 제한점을 극복하려는 시도가 있었다. 하지만 악성 림프종이 의심되어 중심바늘생검을 진행하여 충분한 조직을 채취하여도, 모든 악성 림프종의 아형 분류가 가능한 것이 아 니다. 본 연구에서 악성 림프종으로 의심되어 세침흡인검사 를 진행한 경우는 12 예, 중심바늘생검을 시행한 경우는 10예 였으며, 이 중 두 검사를 같이 시행한 경우는 6 예였다.

세침흡인검사를 통해서는 아형 분류가 불가하여 절개생검 이나 중심바늘생검이 필요하였고, 중심바늘생검을 통해 아형 분류가 진행한 경우는 3 예, 절개생검을 통해 아형 분류가 진 행된 경우는 7예였다. 악성 림프종이 의심되어 중심바늘생검
을 시행한 10 예 중, 아형 분류를 통해 최종 진단이 된 경우는 8 예이며, 이 중에서 4 예는 오직 중심바늘생검을 통해서 얻은 조직을 바탕으로 면역조직화학 검사를 진행하여 림프종 아형 분류까지 가능하였고, 나머지 4예에서는 중심바늘생검에서 아형분류가 불가하여 절개 생검까지 진행하였다. 중심바늘생 검을 통해 $80.0 \%$ 의 정확도를 바탕으로 악성 림프종을 진단 할 수 있었지만, 실제로 중심바늘생검만을 이용하여 아형 분 류까지 진행된 경우의 진단율은 $50.0 \%$ 였다. 이는 악성 림프 종을 진단하는데 중심바늘생검이 절개 생검법을 완벽하게 대체하기에는 부족한 부분이 있다고 사료되며, 악성 림프종 이 의심되었을 때, 중심바늘생검을 시행하기에 무리가 있는 위치에서는 세침흡인검사를 시행 후 악성 림프종이 의심되 면, 아형 분류를 위해 절개생검으로 넘어가도 무리가 없을 것 이라 생각한다. 이러한 의미에서 악성 림프종이 의심될 때, 중 심바늘생검을 시행하기 어려운 경우에는 무리하게 시행하지 않고 세침흡인검사를 적절하게 병행한다면 충분히 진단적 가 치가 있을 것으로 사료된다.

본 연구는 악성 림프종 및 전이성 림프절에 대한 두 검사의 진단적 가치를 비교하기 위해 민감도, 특이도, 양성, 음성 예 측도를 이용하였다. 악성 림프종에서 중심바늘생검은 세침흡 인검사에 비해서 민감도는 낮았으나, 특이도, 양성 예측도가 높았고, 전이성 림프절에서는 중심바늘생검이 세침흡인검사 에 비해서 민감도, 양성 예측도, 음성 예측도가 높았고 특이 도는 동일하였다. 하지만 세침흡인검사의 결과가 중심바늘생 검과 비교해보았을 때 수치상으로 민감도, 특이도에서 큰 차 이가 없는 특이점을 발견하였다.

두 검사를 같이 시행한 조합군의 정확도를 확인해보면, 중 심바늘생검만 시행하였을 때보다 크기가 작은 림프절이나 복 잡한 구조를 이루고 있는 상부 경부 림프절에서의 정확도가 높게 나왔다. 악성 림프종의 정확도는 중심바늘생검만 시행 하였을 때보다 낮게 나왔으나, 나머지에서는 동일하게 확인 되었다. 이는 초기에 중심바늘생검을 시행할 때 세침흡인검 사를 적절하게 병행한다면, 세침흡인검사의 단점인 비진단적 검체 비율을 줄일 수 있고, 중심바늘생검법으로 진행하기 어 려운 조건에서도 보다 향상된 진단학적 결과를 기대해 볼 수 있다고 생각한다.

결론적으로, 저자들은 본 연구를 통해 세침흡인검사와 중 심바늘생검 각각의 장점과 단점을 확인하였고, 진단적 가치 를 평가하였다. 크기와 위치 면에서 세침흡인검사가 상대적으 로 높은 정확도를 보였다. 양성 림프결절에서는 세침흡인검사 가 높은 정확도를 보였고, 악성 림프종에서는 세침흡인검사가 높은 민감도와 정확도를 보인 반면, 중심바늘생검에서 높은 특이도를 보였다. 전이성 림프절에서 두 검사의 정확도는 같 
았으나, 중심바늘생검에서 높은 민감도, 특이도를 확인할 수 있었다. 악성 림프종에서 정확한 진단적 분류 및 치료 계획을 위해서는 면역조직화학검사가 필요한데, 중심바늘생검을 통 해 아형 분류를 시도해 볼 수 있으나 완벽하게 절개 생검을 대체하기에 부족하다고 사료된다. 그러므로 중심바늘생검을 시행하기에 제한이 있는 작은 크기이거나 혈관, 신경 등에 의 해서 접근이 어려운 위치에 있는 임파선에 대해서 먼저 세침 흡인검사를 시행 후에 결과를 보고, 추가적인 검사가 필요할 때 절개생검을 시행하는 것이 여러 부작용을 줄이는 좋은 방 법으로 사료된다.

술자의 경험 및 여러 문헌을 토대로 1) $1 \sim 2 \mathrm{~cm}$ 이하의 작은 크기, 2) 혈관 및 신경으로 인해서 접근이 어려운 위치에 있는 경우, 3) 중심 괴사나 낭종 가능성이 높은 경우, 4) 아직 숙련 도가 부족하여 중심바늘생검을 시행하는 데 있어서 제한점 이 있는 경우에 한에서, ${ }^{2,19-22)}$ 중심바늘생검보다 세침흡인검 사를 먼저 시행해 볼 수 있는 장점이 있다고 본다.

위에서 언급한 경우처럼 크기가 $1 \mathrm{~cm}$ 미만인 경우이거나 혈관 및 신경으로 인해서 접근이 어려운 위치에 있는 경우 그리고 중심 괴사나 낭종의 가능성이 높은 경우에는 중심바 늘생검 시행의 위험성 및 정확도가 떨어질 가능성이 있어서 세침흡인 검사를 우선 시행했기 때문에 림프절의 크기에서 통계학적으로 유의한 차이가 생겼다고 볼 수 있다. 전이성 림 프절의 경우에는 임상적으로 크기가 커서 오는 경우가 많고, 크기가 커지면서 주위 혈관을 누르거나 한쪽으로 편이시키기 때문에 상대적으로 중심바늘생검을 먼저 선택할 수 있었고, 이로 인해 상대적으로 중심바늘생검에서의 악성 진단율이 높았다고 판단된다. 이 두 가지 경우에서 본 연구의 후향적 연구 디자인의 한계가 있었다. 향후에 림프절의 크기 및 악성 종물이 의심되는 경우의 보정을 통한 전향적인 연구가 필요 하다고 판단된다.

또한 본 연구를 통해서 중심바늘생검을 진행하는 경우에 도 초기에는 세침흡인검사를 병행한다면 진단율을 높이는 데 도움이 될 수 있음을 경험했다(통계학적으로는 차이는 없음). 이를 실제 진료에 접목시킨다면 빠른 치료 계획을 세우게 되 고, 환자 만족도를 높일 수 있는 방법이라 생각한다.

\section{Acknowledgments}

None.

\section{Author Contribution}

Conceptualization: Ju Yong Kang, Myung-Chul Lee, Ik Joon Choi. Data curation: Jung Jun Kim, Brian Kim. Formal analysis: all authors. Investigation: Myung-Chul Lee. Methodology: Jung Jun Kim. Resources: Ju Yong Kang. Visualization: Ju Yong Kang. Writing — original draft: Ju Yong Kang. Writing — review \& editing: Ik Joon Choi.

\section{ORCID}

Ik Joon Choi https://orcid.org/0000-0002-9680-3873

\section{REFERENCES}

1) Baier ND, Hahn PF, Gervais DA, Samir A, Halpern EF, Mueller PR, et al. Fine-needle aspiration biopsy of thyroid nodules: Experience in a cohort of 944 patients. AJR Am J Roentgenol 2009;193(4):1175-9.

2) Chae IH, Kim EK, Moon HJ, Yoon JH, Park VY, Kwak JY. Ultrasound-guided fine needle aspiration versus core needle biopsy: Comparison of post-biopsy hematoma rates and risk factors. Endocrine 2017;57(1):108-14.

3) Lioe TF, Elliott H, Allen DC, Spence RA. The role of fine needle aspiration cytology (FNAC) in the investigation of superficial lymphadenopathy; uses and limitations of the technique. Cytopathology 1999;10(5):291-7.

4) Jiang ST, Smith RV. Is core needle biopsy safe and effective for the assessment of head and neck lesions? Laryngoscope 2018;128(12): 2669-70.

5) Jeong WJ, Park MW, Park SJ, Ahn SH. Initial work-up for cervical lymphadenopathy: Back to basics. Eur Arch Otorhinolaryngol 2012;269(10):2255-63.

6) Song JY, Cheong HJ, Kee SY, Lee J, Sohn JW, Kim MJ, et al. Disease spectrum of cervical lymphadenitis: Analysis based on ultrasound-guided core-needle gun biopsy. J Infect 2007;55(4):310-6.

7) Ryu YJ, Cha W, Jeong WJ, Choi SI, Ahn SH. Diagnostic role of core needle biopsy in cervical lymphadenopathy. Head Neck 2015; 37(2):229-33.

8) Park YM, Oh KH, Cho JG, Baek SK, Kwon SY, Jung KY, et al. Analysis of efficacy and safety of core-needle biopsy versus fineneedle aspiration cytology in patients with cervical lymphadenopathy and salivary gland tumour. Int J Oral Maxillofac Surg 2018;47(10): 1229-35.

9) Oh KH, Woo JS, Cho JG, Baek SK, Jung KY, Kwon SY. Efficacy of ultrasound-guided core needle gun biopsy in diagnosing cervical lymphadenopathy. Eur Ann Otorhinolaryngol Head Neck Dis 2016;133(6):401-4.

10) Takashima S, Sone S, Nomura N, Tomiyama N, Kobayashi T, Nakamura H. Nonpalpable lymph nodes of the neck: Assessment with US and US-guided fine-needle aspiration biopsy. J Clin Ultrasound 1997;25(6):283-92.

11) Takes RP, Righi P, Meeuwis CA, Manni JJ, Knegt P, Marres HA, et al. The value of ultrasound with ultrasound-guided fine-needle aspiration biopsy compared to computed tomography in the detection of regional metastases in the clinically negative neck. Int J Radiat Oncol Biol Phys 1998;40(5):1027-32.

12) Robitschek J, Straub M, Wirtz E, Klem C, Sniezek J. Diagnostic efficacy of surgeon-performed ultrasound-guided fine needle aspiration: A randomized controlled trial. Otolaryngol Head Neck Surg 2010;142(3):306-9.

13) Allin D, David S, Jacob A, Mir N, Giles A, Gibbins N. Use of core biopsy in diagnosing cervical lymphadenopathy: A viable alternative to surgical excisional biopsy of lymph nodes? Ann R Coll Surg Eng1 2017;99(3):242-4.

14) Na DG, Kim JH, Sung JY, Baek JH, Jung KC, Lee H, et al. Coreneedle biopsy is more useful than repeat fine-needle aspiration in thyroid nodules read as nondiagnostic or atypia of undetermined significance by the Bethesda system for reporting thyroid cytopathology. Thyroid 2012;22(5):468-75.

15) Sung JY, Na DG, Kim KS, Yoo H, Lee H, Kim JH, et al. Diagnostic accuracy of fine-needle aspiration versus core-needle biopsy for the diagnosis of thyroid malignancy in a clinical cohort. Eur Radiol 2012;22(7):1564-72.

16) Ridder GJ, Kayser L, Technau-Ihling K, Kayser G, Pfeiffer J. [Value 
and utility of minimal-invasive automatic cutting-needle biopsy as a diagnostic technique in the head and neck]. Laryngorhinootologie 2008;87(9):634-40.

17) Aysan E, Kiran T, Idiz UO, Guler B, Akbulut H, Kunduz E, et al. The diagnostic ability of core needle biopsy in nodular thyroid disease. Ann R Coll Surg Engl 2017;99(3):233-6.

18) Huang PC, Liu CY, Chuang WY, Shih LY, Wan YL. Ultrasoundguided core needle biopsy of cervical lymphadenopathy in patients with lymphoma: The clinical efficacy and factors associated with unsuccessful diagnosis. Ultrasound Med Biol 2010;36(9):1431-6.

19) Novoa E, Gürtler N, Arnoux A, Kraft M. Role of ultrasound-guided core-needle biopsy in the assessment of head and neck lesions: A meta-analysis and systematic review of the literature. Head Neck 2012;34(10):1497-503.

20) Engzell U, Jakobsson PA, Sigurdson A, Zajicek J. Aspiration biopsy of metastatic carcinoma in lymph nodes of the neck. A review of 1101 consecutive cases. Acta Otolaryngol 1971;72(1):138-47.

21) Han F, Xu M, Xie T, Wang JW, Lin QG, Guo ZX, et al. Efficacy of ultrasound-guided core needle biopsy in cervical lymphadenopathy: A retrospective study of 6,695 cases. Eur Radiol 2018;28(5):1809-17.

22) Huo JL, Guo YM, Qu R, Liu DS, Chen ZY, Hong W. Diagnostic accuracy and safety of US-guided core needle biopsy versus fine needle aspiration biopsy of thyroid nodules: A Meta analysis. Lin Chung Er Bi Yan Hou Tou Jing Wai Ke Za Zhi 2017;31(14):1103-7. 